\title{
A New Approach for Quorum Sensing System in Several Halophilic Bacteria Isolated from Salt Lake in Central Anatolia
}

\author{
iç Anadolu'daki Tuz Gölü'nden İzole Edilen Çeşitli Halofilik \\ Bakterilerdeki Quorum Sensing Sistemine Yeni Bir Yaklaşım
}

\author{
Research Article \\ Demet Erdönmez ${ }^{*}$, Kübra Erkan Türkmen² and Nilüfer Aksöz ${ }^{2}$ \\ 'Department of Biology, Aksaray University, Aksaray, Turkey. \\ 2Department of Biology, Division of Biotechnology, Hacettepe University, Ankara, Turkey.
}

\begin{abstract}
A B S T R AC T
Q uorum sensing (qs) is the system that microorganisms use to improve common behavior with another population member in their environment. Salt Lake in Turkey that is considered as an extreme environment due to its salt concentration, teems in plankton and bacteria. Especially, it is an important field for halophilic bacteria because it provides suitable growth conditions. In this study, it was determined that 20 halophilic bacteria strain isolated from Salt Lake could produce qs signal molecules which are $\mathrm{N}$-acyl homoserine lactone (HSL) derivatives. For detection of these bacterial signal molecules, thin layer chromatography was utilized by using Chromobacterium violaceum cv026 and Agrobacterium tumefaciens A136 that are biosensor bacteria strains. Genomic analysis of strains that produce signal molecules was carried out via 16s rRNA. Halobacterium salinarium, Salicola sp., Halovibrio, and Halomonas were found to be common in Salt Lake. It was also observed that these strains could produce C6-HSL and C8-HSL signaling molecules and produce biofilms.
\end{abstract}

\section{Key Words}

Homoserine lactone, quorum sensing, halophilic bacteria, Salt Lake.

\section{öz}

\begin{abstract}
Q uorum sensing (qs), bir mikroorganizmanın yaşadığı ortamdaki diğer popülasyon üyeleri ile ortak davranışları geliştirmek için kullandığı bir sistemdir. Içeriğindeki tuz yoğunluğundan dolayı ekstrem ortamlardan sayılan Tuz Gölü, bünyesinde barındırdığı planktonik canlılar ve bakteriler yönünden zengindir. Özellikle tuz gölü uygun üreme koşullarını sağladığı halofilik bakteriler için çok önemli bir alandır. Tuz Gölü>nden izole edilen Halofilik karakterli 20 bakteri türünün qs sinyal moleküllerinden N-asil homoserin lakton $(\mathrm{AHL})$ türevlerini üretebildikleri saptanmıştır. Bu bakteriyel sinyal moleküllerini tespit etmek için biyosensör bakteriler Chromobacterium violaceum cv026 ve Agrobacterium tumefaciens A136 kullanılarak ince tabaka kromatografisinden yararlanılmıştır. Sinyal molekülü üretebilen suşların 16sRNA ile genomik analizleri gerçekleştirilmiştir. Halobacterium salinarium, Salicola türleri, Halovibrio ve Halomonas türlerinin Tuz Gölü içerisinde yaygın olduğu görüldü. Ayrıca bu suşların C6-AHL ve C8-AHL sinyal moleküllerini üretebildikleri ve biyofilm oluşturabildikleri gözlenmiştir.
\end{abstract}

\section{Anahtar Kelimeler}

Homoserin lakton, quorum sensing, halofilik bakteriler, Tuz Gölü.

Article History: Received: January 16, 2018; Revised: Mar 15, 2018; Accepted: Mar 26, 2018.

DOI: $10.15671 /$ HJBC.2018.227

Correspondence to: D. Erdönmez, Department of Biology, Aksaray University, Aksaray, Turkey. 


\section{INTRODUCTION}

T he technological and economic developments initiated by the industrial revolution have made it possible to reach many points of the world through different trade lines. The most common of these lines is the method of shipping method. By shipping, it became ordinary to carry heavy cargos among different points of the world. It is observed that costs of this common trading way have increased with the increase of fuel consumption caused by biofilm on the ship hull formed by interaction between bacteria in the salty environment and ship hull. There is some info about biofilm layer formed by bacteria living in salty environments like sea salt. It is needed to carry out biotechnological and microbialbased studies to prevent biofilm layer formation. A specific part of these studies is carried out for having enough knowledge about how bacteria orient environment, biofilm formation abilities or if bacteria can communicate with each other and if possible, how they communicate? Studies based on usage of bacteria living in a salty environment in biotechnologically different areas are common. Quorum sensing defined as bacterial communication, arise with gene regulation arranged by bacteria population that reach specific majority depending on population [1-5]. Although quorum sensing system is spotted in Gram-negative bacteria first, it is a microbial communication system used for Gram-positive bacteria and some funguses [6-8]. Reproduction and continuity of metabolic activities of microorganisms in different environments show that both structural and cellular specifications of these organisms should be confirmed.

In this study, biofilm formation abilities and detection of quorum sensing signals of different bacteria species isolated from water and soil samples, which are taken from Salt Lake that is a halophilic and extreme environment, are targeted.

\section{MATERIALS and METHODS}

Soil and water samples were taken aseptically from parts of the Salt Lake near Şereflikoçhisar were brought to the laboratory under sterile conditions. 20 of these isolates were used for these study. The isolates which were grown in HS medium were kept Hacettepe University Faculty of Science, Department of Biology, Division of Biotechnology and ASÜBTAM Laboratory of Microbiology at $-20^{\circ} \mathrm{C}$.

\section{Isolation of Halophilic Bacteria}

Soil and water samples were diluted with a sterile saline solution with the ratio of $1: 10(\mathrm{~g} / \mathrm{ml}) .1 \mathrm{ml}$ of each sample were inoculated to the Sea Water medium (Sea Water medium ( $\mathrm{NaCl} 202.5 \mathrm{~g}_{1} \mathrm{MgCl}_{2}$ $17.5 \mathrm{~g}, \mathrm{MgSO}_{4} 24 \mathrm{~g}, \mathrm{CaCl}_{2} 0.9 \mathrm{~g}, \mathrm{KCl} 5 \mathrm{~g}, \mathrm{NaHCO}_{3}$ $0.15 \mathrm{~g}, \mathrm{NaBr} 0.065 \mathrm{~g}$, Yeast extract $5 \mathrm{~g} / \mathrm{L}^{-1} \mathrm{pH} 7.2$ ) and $\mathrm{HS}$ medium $(250 \mathrm{~g}$ of $\mathrm{NaCl}, 20 \mathrm{~g}$ of $\mathrm{MgSO} 4$ $\cdot 7 \mathrm{H}_{2} \mathrm{O}, 3 \mathrm{~g}$ of trisodium citrate $2 \mathrm{H}_{2} \mathrm{O}, 2 \mathrm{~g}$ of $\mathrm{KCl}$ and $10 \mathrm{~g}$ of Oxoid bacteriological peptone $\mathrm{L}-34, \mathrm{pH}$ 6.5-7.4) and incubated for 7 days at $37-39^{\circ} \mathrm{C}, 150$ rpm (Figure 1). $100 \mu$ l of each culture were spread on HS agar plaques. After 7-10 days incubation, selected colonies and control microorganism were inoculated to HS medium again. Third days of incubation colorless colonies and after 10-15 days pink-red colonies were observed at plaques (Figure 2). Gram-negative isolates were selected for this research [1-3].

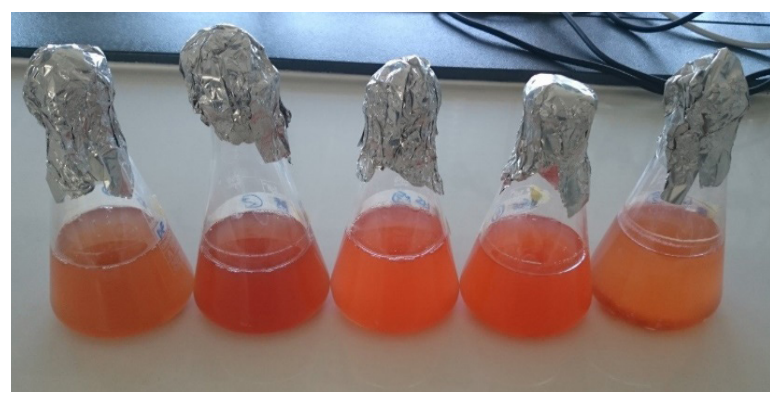

Figure 1. Halophilic bacterial cultures obtained from water and soil samples.

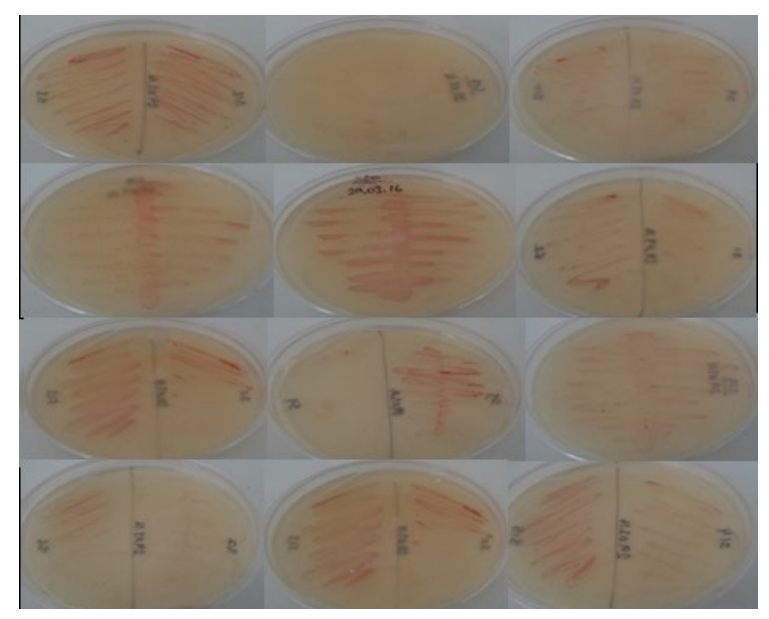

Figure 2. All isolated pure halophilic bacteria. 


\section{Bacterial DNA Isolation}

Biospeedy Bacterial DNA isolation kit was used for DNA isolation and DNA was obtained according to the procedure. The obtained DNA's were stored at $-20^{\circ} \mathrm{C}$ until running for $16 \mathrm{~s}$ rRNA analysis.

\section{Real-Time PCR (Q-PCR)}

Biospeedy Bacterial Diversity Kit was used for identifying bacterial diversity. Primers in which was used during the procedure, were special to 16s rRNA side of bacterial genomic DNA ( forward primer AGA GTT TGA TCC TGG CTC AG and reverse primer AAG GAG GTG ATC CAG CCG CA) $[4,5]$. BIORAD CFX Connect (Bio-Rad Laboratories, USA) Real-time PCR instrument was used for all reactions. The reaction contained $1.5 \mathrm{mM} \mathrm{MgCl}_{2^{\prime}}$ $0.2 \mathrm{mM}$ dNTP mix, 1x Reaction Buffer, $0.1 \mathrm{U}$ Fast Start Taq DNA Polymerase, 1x Eva Green, 4 ng/ $\mu$ template cDNA and $0.5 \mu \mathrm{M}$ of each primer. In the device, the following heat cycle program has been applied with an optimized primer pair (Table 1). During Q-PCR, melting curve analysis was per- formed at $65^{\circ} \mathrm{C}$ to $95^{\circ} \mathrm{C}$ to determine that only the desired product was replicated. Then, it was analyzed by Q-PCR Biorad CFX Connect Software 3.0.

\section{6s RNA Sequencing}

Obtained bacterial amplicon sequence, were determined through Sanger Method with ABI Prism Big Dye Terminator Cycle Sequencing Ready Reaction Kit and ABI Prism 377 DNA Sequencer (Applied Biosystems, USA).

\section{Phylogenetic Analysis}

Obtained sequences from each bacteria were analyzed by Chromas software package version 1.45 (http://www.technelysium.com/au/chromas. html). Sequences were compared with known bacteria species in NCBI DNA databank (BLAST(http://blast.ncbi.nlm.nih.gov/Blast.cgi ) and were determined most similar species, similarity rates, and accession number.

Table 1. Q-PCR reaction contents.

\begin{tabular}{|c|c|c|c|c|}
\hline Detection Format & & Reaction volume & & \\
\hline SYBR Green & & $10 \mu \mathrm{l}$ & & \\
\hline \multicolumn{5}{|l|}{ Programmes } \\
\hline Programme name & Cycle & Analyse mode & & \\
\hline Pre-incubation & 1 & & & \\
\hline Enhancement & 45 & Enumeration & & \\
\hline Melting curve & 1 & Meeting curve & & \\
\hline Cooling & 1 & & & \\
\hline \multicolumn{5}{|l|}{ Temperature } \\
\hline Target $\left({ }^{\circ} \mathrm{C}\right)$ & Mood & $\begin{array}{l}\text { Duration } \\
\text { (hh:mm:ss) }\end{array}$ & $\begin{array}{l}\text { Speed } \\
\left({ }^{\circ} \mathrm{C} / \mathrm{s}\right)\end{array}$ & $\begin{array}{l}\text { Reading } \\
\text { (per }{ }^{\circ} \mathrm{C} \text { ) }\end{array}$ \\
\hline \multicolumn{5}{|l|}{ Pre-incubation } \\
\hline 95 & & 00:10:00 & 4,8 & - \\
\hline \multicolumn{5}{|l|}{ Enhancement } \\
\hline 95 & & 00:00:15 & 4,8 & - \\
\hline 53 & & 00:00:20 & 2,5 & - \\
\hline 72 & Single & $00: 00: 40$ & 4,8 & - \\
\hline \multicolumn{5}{|l|}{ Melting curve } \\
\hline 95 & & 00:00:02 & - & - \\
\hline 65 & & 00:01:00 & - & - \\
\hline 98 & Continuous & - & 0.2 & 10 \\
\hline \multicolumn{5}{|l|}{ Cooling } \\
\hline 35 & Single & 00:00:10 & 2,5 & - \\
\hline
\end{tabular}




\section{Extraction and Purification of $\mathrm{N}-\mathrm{Acyl}$ Homoserine Lactone from Halophilic Bacteria Culture Medium}

For signal molecule extraction, halophilic Gramnegative bacteria culture were inoculated loopfull to $10 \mathrm{ml}$ HS liquid medium and incubated at $37^{\circ} \mathrm{C}$ until stationary phase $[6,7]$. Obtained cultures were centrifuged at $4^{\circ} \mathrm{C}^{\prime} 4000 \mathrm{rpm} 10$ minutes. The supernatant was transferred into a new tube and dichloromethane was added equal volume. Organic phase that was transferred new tube was filtered by $0.2 \mu \mathrm{m}$ pore size sterile syringe filter (non-pyrogenic, Sartorius). Dichloromethane was removed via evaporator [2]. The residue in the tube that included the completely evaporated organic phase was dissolved in $20 \mu \mathrm{L}$ of methanol and stored at $-20^{\circ} \mathrm{C}$ until use $[8,9]$.

\section{Signal Molecules Analysis by Thin Layer Chromatography}

Signal molecules analysis were conducted by Reverse-phase $\mathrm{C} 18$ thin layer chromatography (RP-C18 TLC). N-butanoyl homoserine lactone (C4-HSL), N-hexanoyl homoserine lactone (C6$\mathrm{HSL}), \mathrm{N}$-octanoyl homoserine lactone (C8-HSL) and $\mathrm{N}$-dodecanoyl homoserine lactone (C12-HSL) (Sigma, Germany) molecules were used as standard signal molecules. The signal molecules dissolved in methanol were applied to the reversed phase TLC plates (RP-18 F254; Merck) with a 1.5 $\mathrm{cm}$ interval for each sample loading area up to the starting point. Chloroform- Methanol (95:5, v/v) was prepared as the mobile phase. Mobile phase ran up to $2 \mathrm{~cm}$ below the top of TLC plate. After the separation process was completed, TLC plates were dried in fume hood during $2 \mathrm{~h}$. Chromobacterium violaceum cv026 and Agrobacterium tumefaciens A136 (pCF218)(pCF372) were used as biosensor strains to detect molecules. The dried TLC plates were spread onto $50 \mathrm{ml}$ of $A B$ mineral soft agar medium $\left(50^{\circ} \mathrm{C}\right)+0.9 \mathrm{ml}$ agar containing 10\% Agrobacterium tumefaciens A136 (pCF218) (pCF372) $(100 \mathrm{ml}$ for $48 \mathrm{~h})$ and X-gal $(60 \mu \mathrm{g} / \mathrm{ml})$. Besides, other TLC plates were spread onto LB soft agar medium (\%0.9 agar contained) $+10 \mathrm{ml}$ Chromobacterium violaceum CV026 (24 h culture) culture. When medium solidified, TLC plates were incubated at $30^{\circ} \mathrm{C} 24-48 \mathrm{~h}$ [10-12]. During the experiment, methanol was used as negative control. The spots where AHL molecules located were determined with violaceus or greenish spot occurrence.

\section{Determination of Biofilm Formation Capabilities of Halophilic Bacteria}

Biofilm formation was determined with crystal violet method which is a classical method for biofilm formation [13]. Halophilic isolates were incubated at $37-39^{\circ} \mathrm{C}$ during 7 days in HS medium. Then all isolates were diluted with HS medium at 0.05 O.D. value at $600 \mathrm{~nm}$ and inoculation of isolates was performed with $50 \mathrm{ml}$ culture to 100 $\mathrm{ml} \mathrm{HS}$ medium. All medium which was inoculated before were incubated 200 rpm for 7 days. After incubation, $900 \mu \mathrm{l} \mathrm{HS}$ medium $+100 \mu$ l halophilic bacteria were added to 24 well polystyrene plate. Two different experimental setups were designed for $37-39^{\circ} \mathrm{C}$ and $7-10$ days produced cultures. The medium was discharged from the plate in which incubated cultures. Each well was washed with 1xPBS buffer three times. Washed plate well was dried at $65^{\circ} \mathrm{C}$. Wells were stained with $1 \%$ crystal violet for 2 minutes. After, stained wells were washed at three times and were dried at room temperature. Crystal violet in the well was solubilized with $30 \%$ Acetic acid solution and was measured by spectrophotometer at $595 \mathrm{~nm}[14,15]$.

\section{RESULTS and DISCUSSION}

When the test results were examined, it was observed that the bacterial isolates from soil and water samples could not be grown on medium with higher salt content but they could be grown on medium containing 4-5 $\mathrm{M} \mathrm{NaCl}$, so preliminary definitions were made in accordance with the characteristics of halophilic bacteria. In addition, as gram features, the selection was made among Gram-negative bacillus or coccobacillus morphology isolates [16]. After DNA isolations of the isolates were carried out in the microbiology laboratory of ASUBTAM, their genomic identification was done by Bioeksen $[17,18]$. In this context, according to $16 \mathrm{~S}$ rRNA results for species differentiation, Halobacterium salinarium, Halovibrio, and Halomonaras species were determined to be widespread in Salt Lake (Table 2). 
Table 2. Types of strains isolated by 16 sRNA analysis.

\begin{tabular}{|c|c|c|c|}
\hline Isolate Number & Identity & Similarity Rate & Accession No \\
\hline HS1 & Halobacterium salinarum & $355 / 364(98 \%)$ & FJ236084.1 \\
\hline HS2 & Salicola sp. & $663 / 669(99 \%)$ & KR611161.1 \\
\hline HS3 & Halovibrio sp. & $470 / 585(80 \%)$ & AM774418.1 \\
\hline \multirow{2}{*}{ HS4 } & Salicola sp. & $691 / 719(96 \%)$ & EU931298.1 \\
\hline & Halomonas sp & $690 / 719(96 \%)$ & KF321909.1 \\
\hline HS5 & Salicola sp. & 715/763(94\%) & KR611161.1 \\
\hline HS6 & Salicola sp. & $328 / 358(92 \%)$ & KF511768.1 \\
\hline HS7 & Salicola sp. & $915 / 955(96 \%)$ & KR611161.1 \\
\hline HS8 & Salicola sp. & $529 / 549(96 \%)$ & KR611161.1 \\
\hline \multirow{2}{*}{ HS9 } & Salicola sp. & $468 / 490(96 \%)$ & KR611161.1 \\
\hline & Halomonas sp. & $468 / 490(96 \%)$ & KF321909.1 \\
\hline HS10 & Salicola sp & $621 / 653(95 \%)$ & KR611161.1 \\
\hline HS11 & Halomonas sp. & $663 / 688(96 \%)$ & KF321909.1 \\
\hline HS12 & Halophilic bacterium (Halobacterium salinarum) & 959/1016(94\%) & FJ236084.1 \\
\hline HS13 & Salicola sp. & $641 / 656(98 \%)$ & KR611161.1 \\
\hline HS14 & Salicola sp. & $558 / 568(98 \%)$ & СР003412.1 \\
\hline HS15 & Salicola sp. & $921 / 945(97 \%)$ & KR611161.1 \\
\hline HS15 & Halophilic bacterium & $921 / 945(97 \%)$ & KC142106.1 \\
\hline \multirow{2}{*}{ HS16 } & Salicola sp. & $538 / 628(86 \%)$ & KR611161.1 \\
\hline & Halomonas sp. & $538 / 628(86 \%)$ & KF321909.1 \\
\hline HS17 & Salicola sp. & $503 / 507(99 \%)$ & EU931298.1 \\
\hline HS18 & Halophilic bacterium & $721 / 752(96 \%)$ & FJ236084.1 \\
\hline \multirow{2}{*}{ HS19 } & Salicola sp. & $537 / 572(94 \%)$ & KF511768.1 \\
\hline & Halomonas sp & $537 / 573(94 \%)$ & KF321909.1 \\
\hline HS2O & Salicola sp & 911/953(96\%) & KR611161.1 \\
\hline
\end{tabular}

As a reason for the condensation of genotypically and phenotypically identified strains among certain species in our study, it can be suggested that Dunaliella salina species algae, which is common in Salt Lake during the sampling period, affects the bacterial population. This is supported by the study of Le Chevanton et al. , in which some metabolites that produce Dunaliella algae in the saline environment cause inhibition of the population of bacteria in the environment [19]. Liu et al. found that some gram-negative and positive bacteria, in the study conducted, carried out the excessive proliferation of the algae population, which was expressed as algae bloom [20]. In this context, halophilic bacteria are considered to play an active role in hyperproliferation of Dunaliella in Halobacterium, Salicola, Halovibrio and Halomonas species of bacteria.
Disclosure of the biofilm mechanism regulated by the quorum sensing system, a bacterial communication system, and the detection of signaling molecules that play an active role in the formation of the biofilm mechanism has an important role in explaining the metabolism of bacteria. According to the data obtained from the study; it has been found that HS2, HS5, HS7, HS8, HS9, HS10, HS14, HS15, HS18 and HS19 from halophilic isolates can also produce the $\mathrm{C} 6-\mathrm{AHL}$ signaling molecule in thin layer chromatography in proportion to crossvalidation. On the other hand, it has been found with cross-validation with Agrobacterium sp species that each strain is able to produce signal molecule in the detection of strains which are able to produce signal molecule but signal molecules have not been detected in thin layer chromatography (C8-AHL). It 
has been shown that HS1, HS3, HS5, HS6, HS7, HS8, HS9, HS11, HS13, HS14, HS15, HS16 and HS18 from the isolated strains can produce C8-AHL signaling molecules. The isolates HS5, H7, HS8, HS9, HS14, $\mathrm{HS} 15$, and HS18 were able to produce both $\mathrm{C} 6-\mathrm{AHL}$ and C8-AHL signaling molecules (Table 3).

Enzymes to be used in industrial areas are also required to exhibit high activity in extreme conditions. For this reason, it is necessary to know what kind of signal molecules are produced by many bacterial strains in the extreme conditions, which features are expressed with these signal molecules (enzyme production, antibiotic production, biofilm, exopolysaccharide production) [2,21,22]. Agrobacterium tumefaciens NTL4 (pZRL4) and
Chromobacterium violaceum CV026 have been identified in $\mathrm{N}$-acyl homoserine lactones produced by these bacteria in a study showing that a sufficient number of perceptions also play an important role in hyperphosphorous environments [2]. Since the biofilm formation ability was regulated by the quorum sensing system, the biofilm production characteristics of the isolates producing signal molecules were examined and it was found that HS1, HS5, HS17 strains had higher biofilm forming abilities than the other isolates. 16 sRNA analysis showed that these strains are HS1; Halobacterium salinarium, HS2, and HS17; Salicola sp. It has been found that other isolates have biofilm producing properties even though they are few (Figure 3).

Table 3. The Rf values of the signal molecules of the halophilic isolates in TLC result.

\begin{tabular}{|c|c|c|c|c|c|c|c|c|c|c|}
\hline \multirow[t]{3}{*}{ Strain Number } & \multirow{3}{*}{$\begin{array}{l}\text { AHL } \\
\text { detection with } \\
\text { CV026 }\end{array}$} & \multirow{3}{*}{$\begin{array}{l}\text { AHL } \\
\text { detection } \\
\text { with A136 }\end{array}$} & \multirow[t]{3}{*}{$\frac{\bar{L}}{\simeq}$} & \multirow[t]{3}{*}{$\frac{N}{\alpha}$} & \multirow[t]{3}{*}{$\frac{m}{\alpha}$} & \multirow[t]{3}{*}{$\underset{⿱ 亠 凶}{\triangleleft}$} & $\begin{array}{l}\underset{1}{⿺} \\
\text { 守 }\end{array}$ & 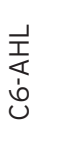 & $\begin{array}{c}+\frac{1}{1} \\
\vdots \\
0 \\
\cup\end{array}$ & \multirow{2}{*}{ 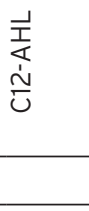 } \\
\hline & & & & & & & \multicolumn{3}{|c|}{ Average Rf values } & \\
\hline & & & & & & & 0,8 & 0.42 & 0.36 & 0.12 \\
\hline HS1 & - & ++ & - & - & 0.35 & - & - & - & $x$ & - \\
\hline HS2 & + & + & - & 0.40 & - & - & - & $x$ & - & - \\
\hline HS3 & - & ++ & - & - & 0.34 & - & - & - & $x$ & - \\
\hline HS4 & - & + & - & 0.42 & - & - & - & $X$ & - & - \\
\hline HS5 & + & ++ & - & 0.40 & 0.34 & - & - & $x$ & $x$ & - \\
\hline HS6 & - & ++ & - & - & 0.30 & - & - & - & $X$ & - \\
\hline HS7 & + & ++ & - & 0.40 & 0.31 & - & - & $x$ & $x$ & - \\
\hline HS8 & + & +++ & - & 0.41 & 0.32 & - & - & $x$ & $x$ & - \\
\hline HS9 & + & ++ & - & 0.42 & 0.28 & - & - & $X$ & $X$ & - \\
\hline HS10 & + & + & - & 0.40 & - & - & - & $x$ & - & - \\
\hline HS11 & - & ++ & - & - & 0.33 & - & - & - & $x$ & - \\
\hline HS12 & - & + & - & - & - & - & - & - & - & - \\
\hline HS13 & - & ++ & - & - & 0.34 & - & - & - & $X$ & - \\
\hline HS14 & + & ++ & - & 0.41 & 0.29 & - & - & $x$ & $x$ & - \\
\hline HS15 & + & ++ & - & 0.42 & 0.31 & - & - & $x$ & $x$ & - \\
\hline HS16 & - & ++ & - & - & 0.33 & - & - & - & $x$ & - \\
\hline HS17 & - & + & - & - & - & - & - & - & - & - \\
\hline HS18 & + & +++ & - & 0.41 & 0.30 & - & - & $x$ & $x$ & - \\
\hline HS19 & + & + & - & 0.39 & - & - & - & $X$ & - & - \\
\hline HS2O & - & + & - & - & - & - & - & - & - & - \\
\hline
\end{tabular}

C4-AHL ; 0,7-0,84 , C6-AHL; 0,39-0,42 , C8-AHL;0,28-0,36, C12-AHL; 0,18-0,22. 


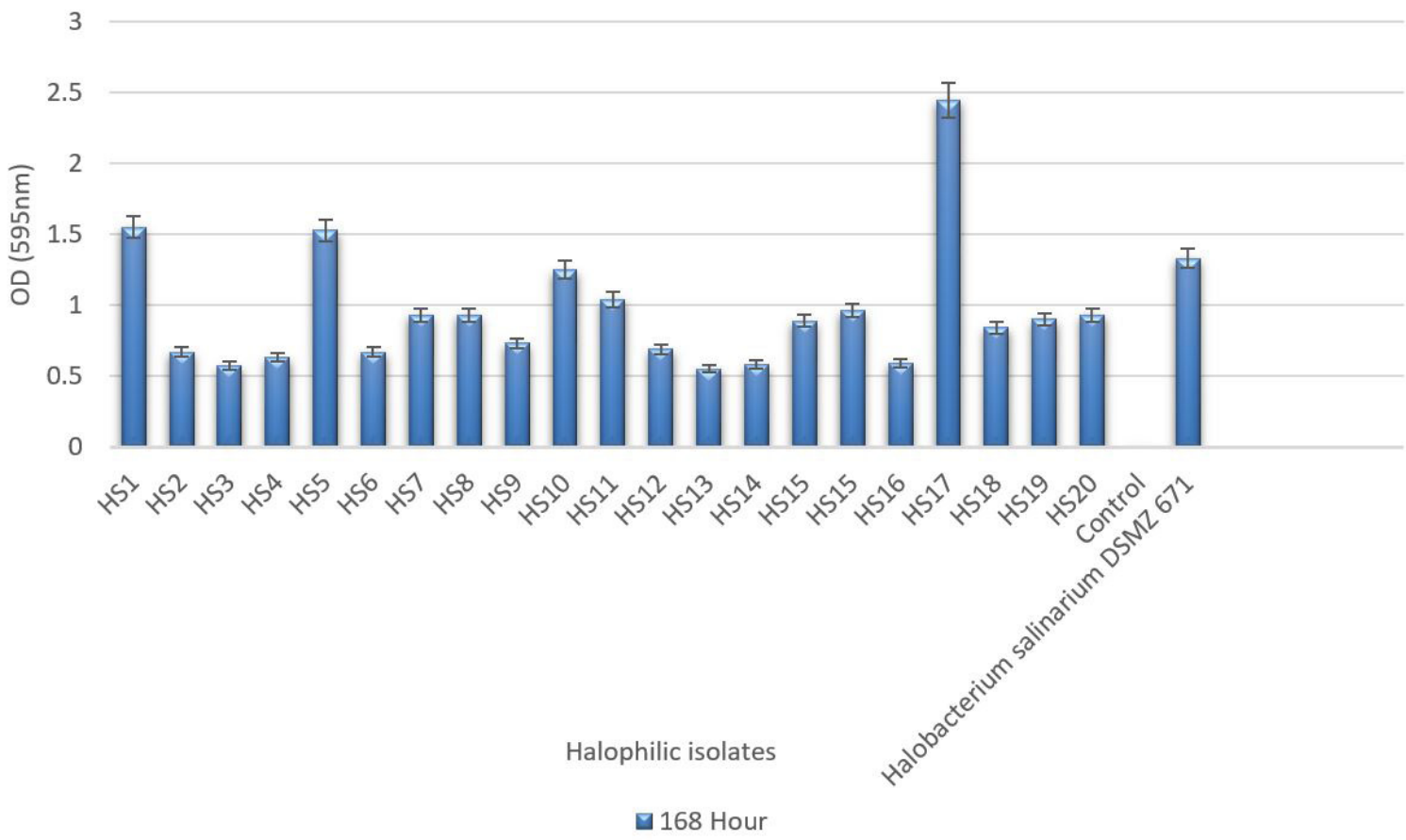

Figure 3. The ability of halophilic isolates to biofilm formation.

The HS12, HS17 and HS2O strains were observed not to produce a quorum sensing signal molecule but were able to generate biofilms. Then these bacteria use different signaling molecules in biofilm formation and it is likely that there is a signal molecule except from the one used as a standard. Figure 3 and Table 3 show that bacteria can produce biofilms regardless of producing quorum sensing signal molecule. In many studies, it is stated that these two systems are coordinated.

In the species of Halomonas anticariensis, In the species Halomonas anticariensis, the quorum sensing system regulates the ability to form biofilms with hanR (the default transcription regulator) and hanl (the autoinducer synthase gene), which are the luxR/luxl homologs [21]. In extreme conditions, it is emphasized by many scientists that this system works more actively $[23,24]$. Formations and densities of biofilms are a result of microbial evolution [25]. Halophilic bacteria in Salt Lake-like environment have developed some features that can give them an advantage over time. Some of them are capable of producing biofilms and being protected from other negativities in the environment. For instance, Salt Lake is exposed to the pollution of some factories and domestic wastes even though it is in the natural conservation areas [26]. Therefore, this leads to pollution, heavy metal accumulation, and many other factors leading to the resistance of the immune system to infection. Another effect is that these bacteria protect themselves by producing biofilms. While biofilm formation is advantageous for salty bacteria, it causes disadvantages in sectors where commercial losses are high, such as maritime transport. In maritime transport, retention of various sea creatures to the parts of the ships exposed to seawater increases depending on the biofilm created by bacteria. This causes the economy to slow down over time and increase fuel consumption. At the same time, a serious amount of resource transfer is required in the elimination of biofilm formation. There are studies based on the reduction or elimination of this condition, but it has been observed that chemicals to be used on the surface of the ship have toxic effects on marine life. In this context, it is necessary to develop low-toxicity and high-availability chemicals for ship surface coatings [27]. First, the identification of quorum sensing molecules, which form biofilms on the surface of the ship and are effective in the formation of this biofilm, should be a priority in order to avoid such losses. Our work carries a preliminary qualification in order to achieve these results. Further research is needed to for future studies on the biofilm properties of halophilic bacteria. Considering the long 
reproduction time of halophilic bacteria, we believe that the signal molecules in the environment may degrade. In addition, these bacteria are thought to have enzymes that can degrade these signaling molecules due to their improved enzyme systems. It has been shown that signal molecules produced by isolated halophilic bacteria change between $\mathrm{C6}$-C8 AHL molecules.

\section{ACKNOWLEDGEMENTS}

This work was supported by Aksaray University Department of Scientific Research Projects Coordination (Projects Number:2015-088)

\section{References}

1. J.J. Nieto, R. Fernandez, Castillo, M.C. Marquez, A. Ventosa, E. Quesada, F. Ruiz-Berraquero, Survey of metal tolerance in moderately halophilic eubacteria, Appl. Environ. Microbiol., 55 (1989) 2385-2390.

2. I. Llamas, E. Quesada, M.J. Martinez-Canovas, M. Gronquist, A. Eberhard, J.E. Gonzalez, Quorum sensing in hal-ophilic bacteria: detection of $\mathrm{N}$-acylhomoserine lactones in the exopolysaccharideproducing species of Halomo-nas, Extremophiles, 9 (2005) 333-341.

3. Ö. Çakıcl, Biochemical and genetic characterization of Halobacterium Salinarium strain isolated from Tuz Lake in Central Anatolia,2004, Mıddle East Technıcal University.

4. K. Ma, R. Conrad, Y. Lu, Responses of methanogen mcra genes and their transcripts to an alternate dry/ wet cycle of paddy field soil, Appl. Environ. Microbiol., 78 (2012) 445-454.

5. J. Penger, R. Conrad, M. Blaser, Stable carbon isotope fractionation by methylotrophic methanogenic archaea, Appl. Environ. Microbiol., 78 (2012) 75967602.

6. M.M. Marketon, J.E. Gonzalez, Identification of two quorum-sensing systems in Sinorhizobium meliloti, J. Bacteriol., 184 (2002) 3466-3475.

7. M.M. Marketon, M.R. Gronquist, A. Eberhard, J.E. Gonzalez, Characterization of the Sinorhizobium meliloti sinR/sinl locus and the production of novel $\mathrm{N}$-acyl homoserine lactones, J. Bacteriol., 184(2002) 5686-5695.

8. V.A. Blana, G.J. Nychas, Presence of quorum sensing signal molecules in minced beef stored under various tem-perature and packaging conditions, Int. J. Food. Microbiol., 173 (2014) 1-8.
9. H. Lade, D. Paul, J.H. Kweon, Isolation and molecular characterization of biofouling bacteria and profiling of quorum sensing signal molecules from membrane bioreactor activated sludge, Int. J. Mol. Sci., 15 (2014) 2255-2273.

10. R.H. González, A. Nusblat, B.C. Nudel, Detection and characterization of quorum sensing signal molecules in Acinetobacter strains, Microbiol. Res., 155 (2001) 271-277.

11. D. Anbazhagan, M. Mansor, G.O. Yan, M.Y. Md Yusof, H. Hassan, S.D. Sekaran, Detection of quorum sensing sig-nal molecules and identification of an autoinducer synthase gene among biofilm forming clinical isolates of Acinetobacter spp, PloS one, 7 (2012)

12. S.D. Saroj, P.N. Rather, Streptomycin inhibits quorum sensing in Acinetobacter baumannii, Antimicrob. Agents Chemother., 57 (2013) 1926-1929.

13. J.H. Merritt, D.E. Kadouri, G.A. O'Toole, Growing and analyzing static biofilms, Curr. Protoc. Microbiol., Chapter 1 (2005) Unit 1B.1.

14. D. Mack, W. Fischer, A. Krokotsch, K. Leopold, R. Hartmann, H. Egge, R. Laufs, The intercellular adhesin in-volved in biofilm accumulation of Staphylococcus epidermidis is a linear beta-1, 6-linked glucosaminoglycan: purification and structural analysis. J. Bacteriol., 178 (1996) 175-183.

15. X. Wang, J.F. Preston, T. Romeo, The pgaABCD locus of Escherichia coli promotes the synthesis of a polysaccha-ride adhesin required for biofilm formation, J. Bacteriol., 186 (2004) 2724-2734.

16. S.B. McGee, C.A. Orengo, M.E. Kunik, V.A. Molinari, R.H. Workman, Delirium in geropsychiatric patients: patient characteristics and treatment outcomes, J. Geriatr. Psychiatry Neurol., 10 (1997) 7-10.

17. R. Rohban, M.A. Amoozegar, A. Ventosa, Screening and isolation of halophilic bacteria producing extracellular hydrolyses from Howz Soltan Lake, Iran, J. Ind. Microbiol. Biotechnol., 36 (2009) 333-340.

18. C. Sánchez Porro, S. Martin, E. Mellado, A. Ventosa, Diversity of moderately halophilic bacteria producing extra-cellular hydrolytic enzymes, J. Appl. Microbiol., 94 (2003) 295-300.

19. M. Le Chevanton, M. Garnier, G. Bougaran, N. Schreiber, E. Lukomska, J.B. Bérard, E. Fouilland, O. Bernard, J.P. Cadoret, Screening and selection of growth-promoting bacteria for Dunaliella cultures, Algal Res., 2 (2013) 212-222.

20. J. Liu, A.J. Lewitus, P. Brown, S.B. Wilde, Growthpromoting effects of a bacterium on raphidophytes and other phytoplankton, Harmful Algae, 7 (2008) $1-10$.

21. A. Tahrioui, E. Quesada, I. Llamas, The hanR/hanl quorum-sensing system of Halomonas anticariensis, a moder-ately halophilic bacterium, Microbiology, 157 (2011) 3378-87. 
22. A. Tahrioui, M. Schwab, E. Quesada, I. Llamas, Quorum sensing in some representative species of halomonadaceae, Life (Basel), 3 (2013) 260-75.

23. B.A. Doğaner, L.K. Yan, H. Youk, Autocrine signaling and quorum sensing: Extreme ends of a common spectrum, Trends Cell Biol., 26 (2016) 262-271.

24. K. Montgomery, J.C. Charlesworth, R. Lebard, P.T. Visscher, B.P. Burns, Quorum Sensing in Extreme Environments, Life, 3 (2013) 131-148.
25. H.P. Steenackers, I. Parijs, K.R. Foster, J. Vanderleyden, Experimental evolution in biofilm populations, FEMS Microbiol. Rev., 40 (2016) 373-397.

26. A. Kılıç, E. Uyanık, Tuz Gölü'nde oluşan kirlenmenin göl üzerindeki etkilerinin araştırılması, 4. Endüstriyel Hammaddeler Sempozyumu 18-19 Ekim, (2001) 135145.

27. M.P. Schultz, J.A. Bendick, E.R. Holm, W.M. Hertel, Economic impact of biofouling on a naval surface ship, Biofouling., 27 (2011) 87-98. 